\section{Effects of Home Value, Home Age, and Lot Size on Lawn-watering Perceptions and Behaviors of Residential Homeowners}

\author{
Dale J. Bremer ${ }^{1,3}$, Steven J. Keeley ${ }^{1}$, and Abigail Jager ${ }^{2}$
}

ADDITIONAL INDEX wORDs. turfgrass, landscape, irrigation, water conservation, water quality, lawn appearance, green lawns

\begin{abstract}
SUMMARY. Urbanization is increasing the land area covered with turfgrasses, which may affect water quantity and quality. Our objective was to understand lawnwatering habits of homeowners in Olathe and Wichita, KS, based on home value, home age, and lot size. Surveys were mailed to 9992 homeowners in Olathe and 15,534 in Wichita, with a return rate of $12 \%$. Owners of more expensive and/or newer homes were more likely to water frequently, water on a routine schedule, feel it was important to have a green lawn, have an in-ground sprinkler system, and sweep or blow grass clippings and lawn care products off impervious surfaces. Owners of less expensive and/or older homes were more likely to never water or water infrequently, water based on the lawn's appearance rather than on a routine schedule, consider it less important to have a green lawn; not have an in-ground sprinkler system, and leave grass clippings and lawn care products on impervious surfaces rather than blowing them off. A small percentage of homeowners who swept or blew clippings and/or lawn-care products did so into streets/storm drains. Owners of less expensive and/or older homes were somewhat more likely to engage in this practice. Educational efforts to improve lawn water conservation should be concentrated on homeowners in more expensive and/or newer homes because they water more frequently and routinely. Efforts to protect surface water quality should include homeowners of less expensive and/or older homes.
\end{abstract}

W ith urbanization, significant tracts of natural ecosystem and agricultural land are being replaced with turfgrass (Alig et al., 2004; U.S. Geological Survey, 1999). In the United States, turfgrasses are estimated to cover 16 to 20 million ha of urbanized land, or up to $18 \%$ of the land area in some regions [Morris, 2003; U.S. Department of Agriculture (USDA), 2004, 2006]; this represents an area three times larger than any irrigated crop (Milesi et al., 2005). Furthermore, urbanization in the United States and elsewhere is projected to continue to increase rapidly (Alig et al., 2004), indicating a continued expansion of land area covered with turfgrasses.

Contribution no. 15-025-J from the Kansas Agricultural Experiment Station.

This research was funded by the USDA National Integrated Water Quality Program (NIWQP) and the Kansas Turfgrass Foundation. Funding of survey printing and mailing was provided by the Wichita Dept. of Environmental Services and Olathe Municipal Services.

We appreciate the assistance of Laura Moley, Jack Fry, and Cathie Lavis in development of the survey.

${ }^{1}$ Department of Horticulture, Forestry \& Recreation Resources, Kansas State University, 2021 Throckmorton Hall, Manhattan, KS 66506

${ }^{2}$ Department of Statistics, 101 Dickens Hall, Kansas State University, Manhattan, KS 66506

${ }^{3}$ Corresponding author. E-mail: bremer@ksu.edu.
The rapid increase of turfgrass in the landscape may have significant implications for water quality and quantity. A number of studies have linked urbanization with declining water quality in surface and groundwater reservoirs due to increased concentrations of nutrients and pesticides, some of which are used in lawns (Carey et al., 2013; Hamilton et al., 2004; King and Balogh, 2001; Petrovic and Easton, 2005; U.S. Geological Survey, 2001). Water quality in urban areas may be affected by runoff or leaching of fertilizer nutrients and pesticides from lawns, but runoff from impervious surfaces is the greatest concern. Runoff from lawns or impervious surfaces may happen during intense rainstorms, when turfgrass is overirrigated, or when irrigation systems are improperly adjusted (Brezonik and Stadelmann, 2002; Morton et al., 1988; Petrovic, 1990).
The greatest opportunity for conserving water and minimizing runoff and leaching in urban areas may be in residential lawns. From $50 \%$ to as much as $80 \%$ of all land area covered with turfgrass in the United States is composed of residential lawns (Grounds Maintenance, 1996; USDA, 2004, 2006), and an estimated 30\% of all residential water use is devoted to outdoor purposes (Vickers, 2001). However, inaccurate perceptions about water requirements for turfgrass, or embellished expectations about lawn appearance (e.g., maintaining perfectly green lawns, even during drought) may result in overirrigation. This indicates a need to change the behavior of home dwellers to reduce their irrigation inputs and thus, conserve water and improve water quality.

In three Kansas cities, perceptions about and practices of lawn watering by residential homeowners were influenced by a number of factors including local climate, water costs, and recent water shortages (Bremer et al., 2013). Furthermore, homeowners with in-ground sprinkler systems watered their lawns more frequently and routinely, and wanted their lawns green all the time, more than homeowners without in-ground sprinklers (Bremer et al., 2012). Factors such as home value, home age, and lot size could also affect perceptions about and practices of lawn watering by homeowners. Presumably, residential homeowners with newer, more expensive homes may have higher expectations for maintaining a green lawn all the time, and fewer concerns about spending money for that purpose. Evaluating such trends is important because it could help identify homeowners that use more water. Educational efforts designed to conserve water and protect water quality in urban watersheds could then be directed at appropriate homeowner groups (Endter-Wada et al., 2008).

Therefore, our objectives were to evaluate how home value, home age, and lot size affected the perceptions,

\begin{tabular}{lllc}
\hline $\begin{array}{l}\text { Units } \\
\text { To convert U.S. to SI, } \\
\text { multiply by }\end{array}$ & U.S. unit & SI unit & $\begin{array}{l}\text { To convert SI to U.S., } \\
\text { multiply by }\end{array}$ \\
\hline 0.4047 & $\mathrm{acre}(\mathrm{s})$ & $\mathrm{ha}$ & 2.4711 \\
0.0929 & $\mathrm{ft}^{2}$ & $\mathrm{~m}^{2}$ & 10.7639 \\
2.54 & inch(es) & $\mathrm{cm}$ & 0.3937
\end{tabular}


knowledge, and behaviors of residential homeowners with regard to irrigation of their lawns during summer months. To that end, survey responses were compared among homeowners with differing home values, home ages, and lot sizes.

\section{Materials and methods}

Surveys were mailed to residents in Olathe and Wichita, KS, in 2009. Lists of addresses of residential homeowners were obtained from the municipal utility in each city. For Olathe, the list of addresses included information about home value, home age, and lot size for each address. None of that information was available for the addresses in Wichita. Thus, the factors of home value, home age, and lot size were evaluated for the Olathe population. For Wichita, median home values for each of the 23 zip codes were available (U.S. Census Bureau, 2013). Consequently, zip codes were grouped according to their median home values and evaluated with survey responses corresponding to the same zip codes in Wichita. Although this was a less precise data set than from Olathe, it provided a unique opportunity to compare survey responses by home value from Olathe with an independent population from Wichita.

Ranges for different categories of home value, home age, and lot size were determined based on local housing markets. For home value, survey responses were compared among homes valued at $<\$ 150,000 ; \$ 150,000$ to $\$ 200,000 ; \$ 200,000$ to $\$ 250,000$; and $>\$ 250,000$. Home ages were grouped according to the number of years since they were built: 1) $>30$ years old (1979 and earlier); 2) 15 to 30 years old (1980 to 1995); and 3 ) $<15$ years old (1996 to 2008). Lot sizes were sorted into three groups: 1 ) $\left.<9000 \mathrm{ft}^{2} ; 2\right) 9000$ to $14,000 \mathrm{ft}^{2}$; and $>14,000 \mathrm{ft}^{2}$. Lot size did not equate strictly to lawn size, but also included the home, garage, impervious surfaces, etc. For Wichita, the home values from the online database, which were averaged across each zip code, were grouped into the same home value ranges as in Olathe.

STUdy locations. Olathe is located in the Lower Kansas River Watershed and is a suburb of the larger Kansas City metropolitan area that straddles the Kansas and Missouri state borders. Kansas City ranked 29th in the United States in 2010 for the amount of land area covered by urban landscapes (U.S. Census Bureau, 2013). Olathe grew by $35 \%$ from 2000 to 2010 and was ranked 24th in the list of fastest growing cities in the nation in 2008; the population in 2010 was 125,872 . Olathe is an affluent suburb whose residents typically maintain high-input lawns; median annual household income from 2006 to 2010 was $\$ 75,228$. In Olathe, water is generally plentiful except during peak water usage in summer months.

Wichita is in the Middle ArkansasSlate Watershed, 160 miles to the west-southwest of Olathe, and receives about 9.2 inches less precipitation annually than Olathe. Wichita is the 49th largest city in the United States and grew by $11 \%$ from 2000 to 2010; the population in 2010 was 382,368 (U.S. Census Bureau, 2013). Additional details about the cities of Olathe and Wichita can be found in Bremer et al. $(2012,2013)$.

Survey DEVELOPMENT. A survey was developed to determine how residential homeowners make decisions about watering their lawns, including the frequency of and amount of water applied during irrigation in the summer months of June, July, and
August. Homeowners were asked how frequently they watered their lawns, how they made the decision about when to water, how important it was to keep their lawns green all the time, and whether they had an inground sprinkler system. Surveyees were asked if they knew how much water their lawn required and how much water they were applying when they irrigated. They were also asked whether they swept or blew their driveways after mowing or applying lawn care products, and if they did, whether they swept or blew them back into their lawns or into the street or storm drains. Other questions were asked, which were not analyzed in this research. A more complete description of survey questions is in Bremer et al. $(2012,2013)$.

The survey consisted of five-point Likert-scaled items (Likert, 1932) and multiple choice questions. The Likertscaled items were ranked from 1 to 5 where $1=$ not important and $5=$ very important. For multiple choice questions, participants were asked to select one answer out of two to six options to represent their response to a given question. Where only two options were offered, the question called for either a yes or no response.

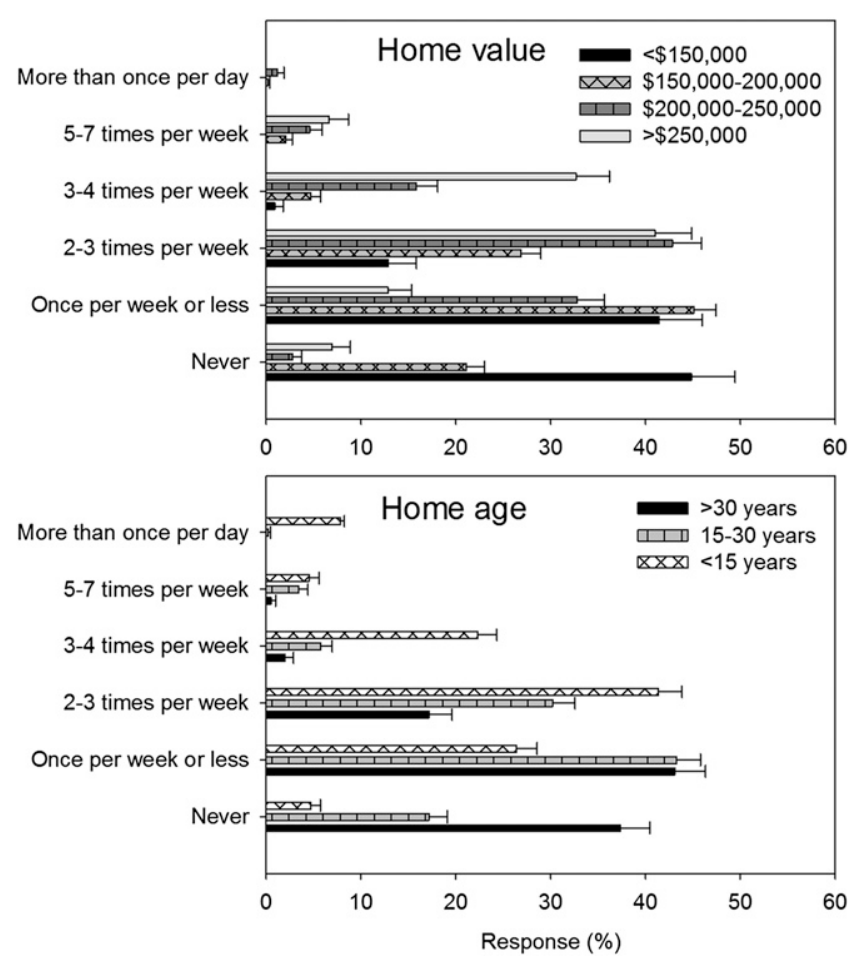

Fig. 1. Responses of residential homeowners in Olathe, KS, grouped by home value (top) and home age (bottom), to the survey question "how often do you water your lawn during dry periods of the summer?" Error bars denote the SE. 
Because the targeted population was residential homeowners, all respondents were asked whether they actually owned their homes. In addition, they were asked whether they watered and maintained their lawn themselves. If any respondent did not own their own home or water and maintain their own lawn, their surveys were discarded from the final analysis. As an incentive to participate in the survey, all respondents were entered into a drawing for a $\$ 100$ gift card (one per city) from a local homeimprovement department store.

Population and sample. The total population of residential homeowners was 26,333 in Olathe, and 98,708 in Wichita. To ensure that sampling was uniform geographically across each city, a stratified design was employed. This involved dividing each city arbitrarily into sections. Addresses were then selected randomly from within each section based on its population proportionate to the total population of the city. Accordingly, Wichita was divided by zip codes into 23 sections and Olathe was divided into 13 sections.

Each address selected received a one-page, trifold survey mailer. Homeowners were asked to complete the survey and return it postage paid. The total number of surveys mailed to residential homeowners was 9992 in Olathe on 27 May 2009 and 15,534 in Wichita on 2 July 2009. In total, the number of surveys returned by residents included 1772 from Wichita and 1110 from Olathe. Thus, the total return rate was $11.4 \%$ for Wichita and $13.1 \%$ for Olathe.

Like many mail surveys, this survey had a low response rate (Dillman, 1991). However, a survey with a low response rate can provide meaningful conclusions about the population. For this to be true, we assumed that the homeowners that responded to the survey were a random subgroup of the homeowners who were mailed surveys. In other words, respondents and nonrespondents would have provided similar answers to the survey questions. Furthermore, when no information is available regarding characteristics of the nonrespondents, we cannot quantify the amount of potential nonresponse bias present. In this case, since no follow-up surveys were attempted, we do not have information on nonrespondents (Dey, 1997).
Data Analysis. Data were analyzed using the statistical program $\mathrm{R}$ (version 2.13, R Core Development Team, 2011). For each urban area, proportions (and standard errors) of respondents in each category for each survey question were computed using the stratified sampling design of the survey. Additional adjustments were made for sampling from finite populations (Scheaffer et al., 1979). Because the sampling design for each city was independent of the other city, data for Olathe and Wichita were analyzed independently. Within a city, proportions were estimated for each of the geographic sections (23 zip codes for Wichita and 13 sections for Olathe). For Wichita, the proportions for zip codes with an average home value within each home value range were weighted according to the populations of the zip codes and then combined to give an overall estimate of the proportion for each home value range. For Olathe, proportions and standard

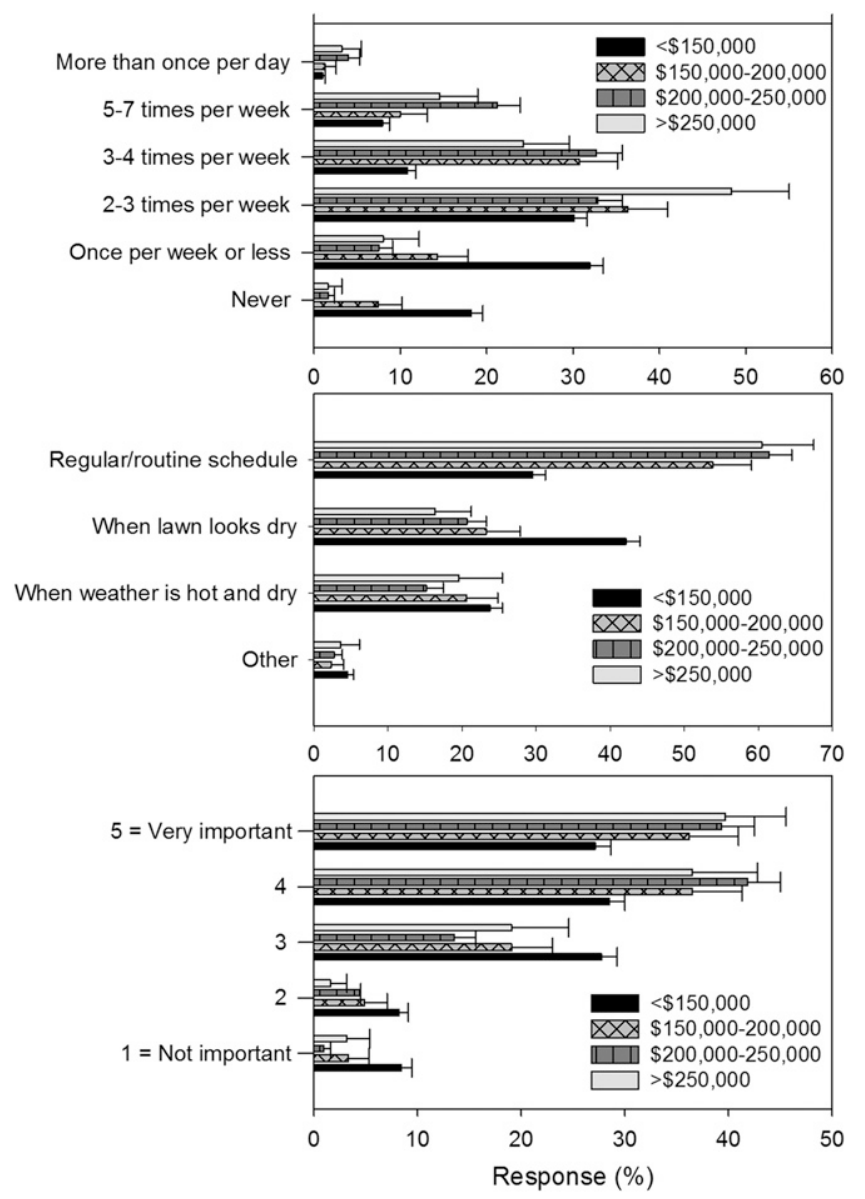

Fig. 2. Responses of residential homeowners in Wichita, KS, to the questions "how often do you water your lawn during dry periods of the summer?" (top); "how do you decide when it is time to water your lawn?" (middle); and the statement "I like my lawn to look green all the time" (bottom). Error bars denote SE. 
regular schedule was likely related to the tendency of homeowners with inground sprinkler systems to water on a regular/routine schedule, described by Bremer et al. (2012). This difference notwithstanding, higher percentages of homeowners in all lot-size categories decided when to water based on the lawn's appearance ( $45 \%$ to $50 \%$ of respondents from each lot-size category), than watered on a regular schedule. Home value and home age were much more important determinants of lawn-watering behaviors than lot size.

Home VAlue AND HOME AGE. Responses by Olathe homeowners to the question "how often do you water your lawn during dry periods of the summer?" indicated that owners of the highest-value homes (homes valued at $>\$ 250,000)$ were much more likely to water frequently, compared with owners of less expensive homes (Fig. 1). Forty percent of highest-value homeowners watered at least three to four times per week; by contrast, $<1 \%$ of lowest-value homeowners (homes valued at $<\$ 150,000$ ) and $<7 \%$ of moderately low-value homeowners (homes valued from $\$ 150,000$ to $\$ 200,000)$ watered at least three to four times per week. The vast majority of lowest-value homeowners watered once per week or less (86\%), with $45 \%$ indicating they never watered their lawns.

In Wichita, where home value was estimated based on U.S. Census data, trends were similar to Olathe, but less dramatic (Fig. 2, top). While owners of higher-value homes tended to water more frequently, there were fewer differences in watering frequency among owners in the upper three categories $(\$ 150,000$ and above). However, as in Olathe, owners of lowest-value homes were much more likely to never water, or to water once per week or less.

When considering responses to this question based on home age, owners of newer homes $(<15$ years) were more likely to water frequently, and owners of older homes less frequently or never (Fig. 1). Owners of oldest-age homes ( $>30$ years) were much more likely to never water their lawns, with $37 \%$ indicating they never watered, compared with $17 \%$ of owners of middle-age homes (15 to 30 years) and only $5 \%$ of owners of newer homes. It is likely that newer homes were generally more expensive than older homes; therefore, these results may reflect the relationship between home value and watering frequency, as discussed above.
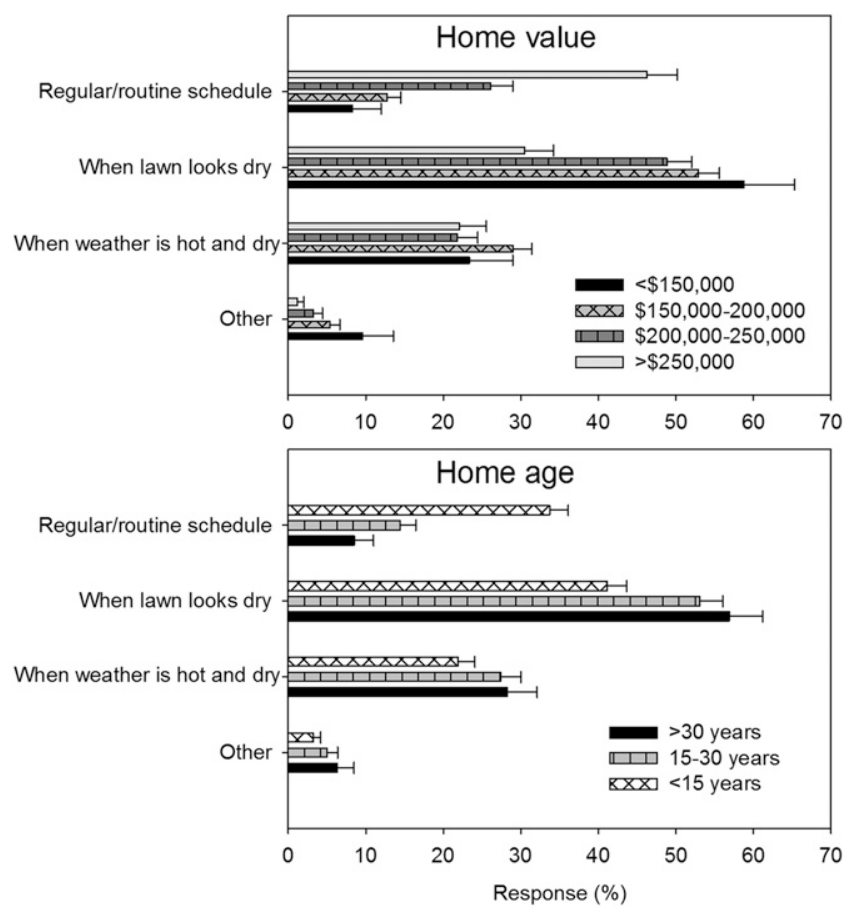

Fig. 3. Responses of residential homeowners in Olathe, KS, grouped by home value (top) and home age (bottom), to the survey question "how do you decide when it is time to water your lawn?" Error bars denote the SE.

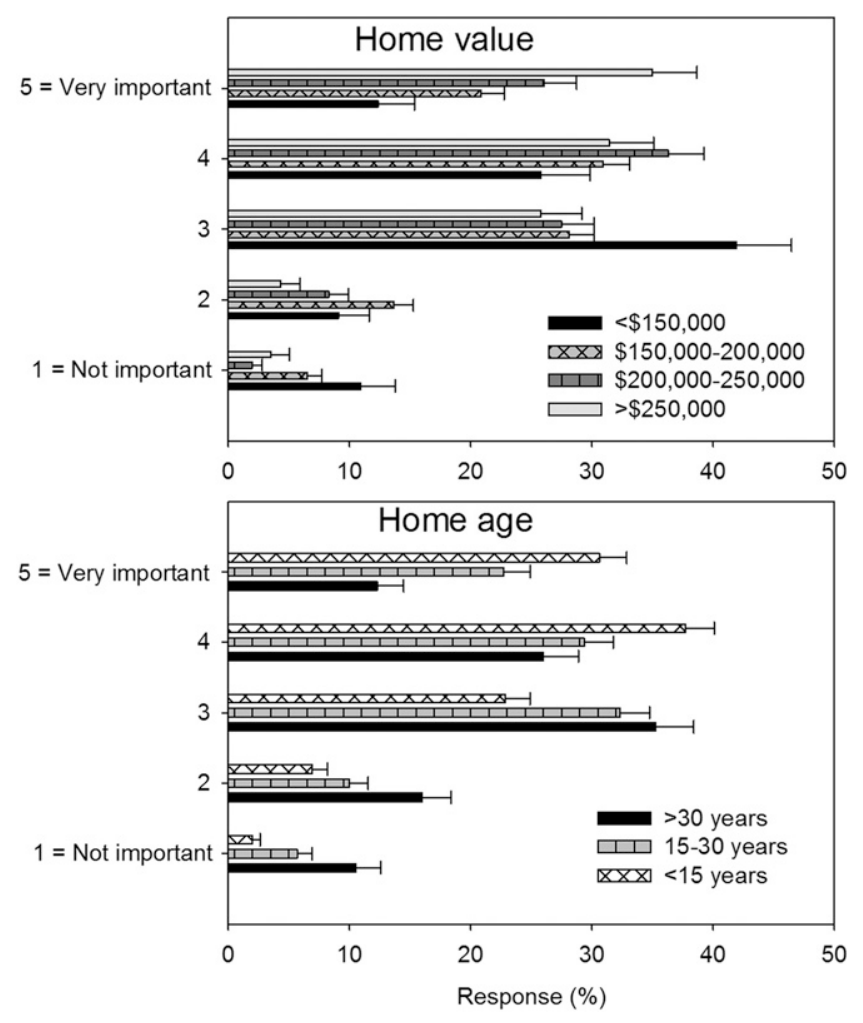

Fig. 4. Responses of residential homeowners in Olathe, KS, grouped by home value (top) and home age (bottom), to the statement "I like my lawn to look green all the time." Error bars denote SE. 
highest-value homes were much more likely to water on a regular schedule than owners of lower-value homes (Fig. 3). Forty-six percent of highest-value homeowners watered on a regular schedule, while only $8 \%$ and $13 \%$ of lowest-value and moderately low-value homeowners did so, respectively. By contrast, homeowners in the three categories below highest-value were much more likely than highest-value homeowners to water based on the appearance of the lawn.

In Wichita, trends were similar, but as with watering frequency, there was little difference in how watering decisions were made among owners in the upper three categories $(\$ 150,000$ and above); the greatest difference was between lowest-value homeowners and owners of more expensive homes (Fig. 2, middle). Owners of homes in the three higher-value categories were much more likely to water on a regular schedule compared with lowest-value homeowners $(54 \%$ to $61 \%$ compared with $30 \%$, respectively). Conversely, lowest-value homeowners were much more likely to water based on the lawn's appearance $(42 \%$, compared with only $17 \%$ to $23 \%$ of higher-value homeowners).

When considering responses to this question based on home age, owners of newer homes were much more likely to water on a regular schedule $(34 \%)$, compared with owners of middle-age homes (14\%) and oldestage homes (9\%) (Fig. 3). As with watering frequency, this is likely a reflection of the relationship between home value and watering decisions.

Survey responses also revealed that $80 \%$ to $90 \%$ of Olathe homeowners in all home value categories did not know how much water they applied when irrigating their lawns, and $63 \%$ to $72 \%$ did not know how much water their lawns required (data not shown). Responses were similar when homeowners were queried based on home age. This knowledge deficit likely results in inefficient and wasteful irrigation practices. Teaching homeowners how to conduct an irrigation audit would help improve knowledge in these areas and should improve the efficiency and effectiveness of lawnirrigation practices (Nelson, 1992).

Responses by Olathe homeowners to the statement "I like my lawn to look green all the time" showed a strong relationship between home value and agreement with this statement (Fig. 4). Thirty-five percent of highest-value homeowners considered it "very important," compared with $26 \%$ of moderately high-value homeowners (homes valued from $\$ 200,000$ to $\$ 250,000), 21 \%$ of moderately low-value homeowners, and only $12 \%$ of lowest-value homeowners. Conversely, lowest-value homeowners were more likely to be neutral in response to this question, or to consider it "not important." A related statement in the survey was, "I want to make sure that I keep my lawn alive during hot/dry weather." Over $50 \%$ of Olathe's highest-value and moderately high-value homeowners strongly agreed with this statement, compared with $<20 \%$ of lowest-value homeowners; similarly, over $50 \%$ of owners of newer homes strongly agreed, compared with $<25 \%$ of oldest-age homeowners (data not shown). Most homeowners believe a well-kept lawn increases property values (Sewell et al., 2010), and it seems likely that higher-value homeowners greater desire for a healthy, green lawn reflects a greater concern for protecting their investment in their home. By contrast, lowestvalue homeowners were much more concerned with keeping their water bill from getting too high, with $>55 \%$ indicating this was "very important," compared with $35 \%$ of highest-value homeowners (data not shown).

In Wichita, the most notable difference in response to the statement, "I like my lawn to look green all the time" was once again between lowest-value homeowners and all owners in the three more expensive categories (Fig. 2, bottom). Thirtysix to forty percent of higher-value homeowners considered it very important for their lawn "to look green all the time," compared with only
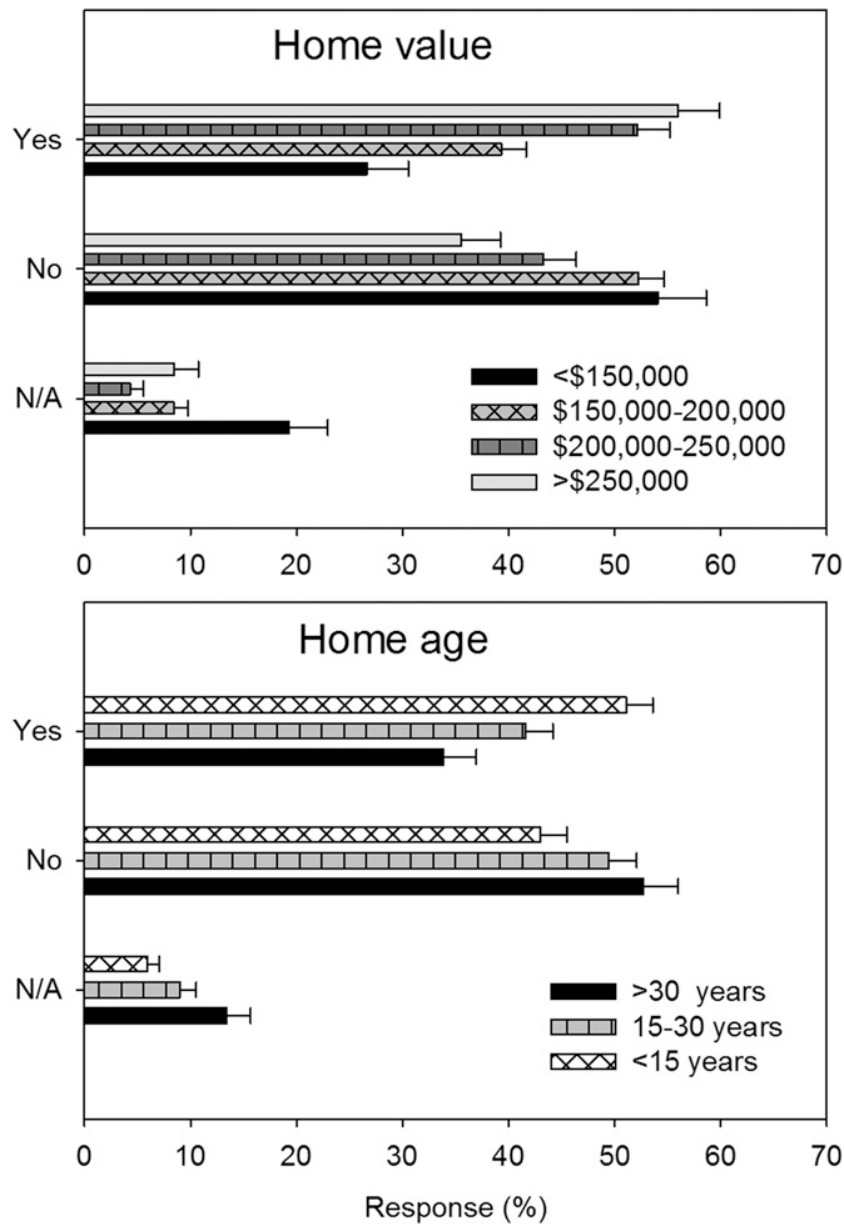

Fig. 5. Responses of residential homeowners in Olathe, KS, grouped by home value (top) and home age (bottom), to the question "do you sweep or blow your driveway after applying lawn-care products?" Error bars denote SE and N/A indicates not applicable. 
$27 \%$ of lowest-value homeowners. As in Olathe, lowest-value homeowners were more likely than other groups to be neutral in response to this question or to consider it "not important." It is interesting to note that, overall, having a green lawn all the time was somewhat more important to Wichita respondents than to Olathe respondents. Wichita homeowners were also more concerned with keeping their lawn alive during hot/dry weather, with $79 \%$ of highest-value homeowners and $48 \%$ of lowest-value homeowners considering this "very important." The greater overall concern with lawn color and health among Wichita homeowners may be due to the more extreme summer climate in Wichita; the evaporative demand in Wichita during June, July, and August is 28.0 inches, compared with 24.2 inches in Olathe (Sophocleous, 1998). Precipitation during the same months is 12.2 inches in Wichita and 14.3 inches in Olathe. Combined, this makes it more challenging to keep a cool-season lawn healthy in Wichita.

In general, the response trends between the two cities were similar for all the questions discussed thus far, which suggests these results represent a cross section of residential homeowners elsewhere (Bremer et al., 2013). Olathe responses tended to segregate more neatly by home-value category, while Wichita responses tended to segregate between lowest-value homeowners and the three upper-value groups (with the three upper-value groups often responding similarly). Tidier segregation in the Olathe responses may be partially related to higher resolution in the Olathe dataset (i.e., home values were known for each address in Olathe, while home values were averaged across each zip code in Wichita). In addition, the slightly different response pattern from the two cities may possibly be explained by the difference in summer climate, noted above. The higher evaporative demand in Wichita means that watering lawns less frequently, and/or with lower amounts of water, will result in faster lawn decline.

As with watering frequency and watering decisions, responses to the statement "I like my lawn to look green all the time" based on home age showed a similar trend to responses based on home value. That is, owners of newer homes were more likely to consider having a green lawn "all the time" very important, while owners of older homes were more likely to be neutral or to consider it "not important" (Fig. 4).

In general, the majority of homeowners fertilize their lawns $[\approx 40 \%$ to $>80 \%$ (Dietz and Abraham, 2011; Polsky et al., 2014)], and virtually all homeowners mow; grass clippings and fertilizers left on impervious surfaces are likely to be washed into storm drains, representing a hazard to surface water quality (Petrovic and Easton, 2005). Responses by Olathe homeowners to the questions "do you sweep or blow your driveway after applying lawn-care products?" and "do you sweep or blow your driveway after mowing (grass clippings)?" showed that the higher the home value, and the newer the home, the more likely homeowners were to sweep or blow (Figs. 5 and 6).
Overall, a much higher percentage of homeowners indicated that they sweep or blow after mowing (69\% to $70 \%$, averaged across all home values or home ages) than after applying lawn-care products ( $42 \%$ to $44 \%$ ). The vast majority of homeowners who sweep or blow, do so back into the lawn (88\% to $97 \%$; data not shown), which helps protect surface water quality. However, while a small percentage of respondents indicated they sweep or blow directly into streets or storm drains $(7 \%$ to $8 \%$, averaged across all home values or home ages), this percentage equates to over 1800 residential homeowners in Olathe and has serious implications for surface water quality. Lowest-value homeowners were more likely to sweep or blow directly into streets or storm drains ( $12 \%$, compared with $3 \%$ of highest-value homeowners; data not shown). Since lower-value homeowners were also more likely to leave grass clippings or lawn care products laying
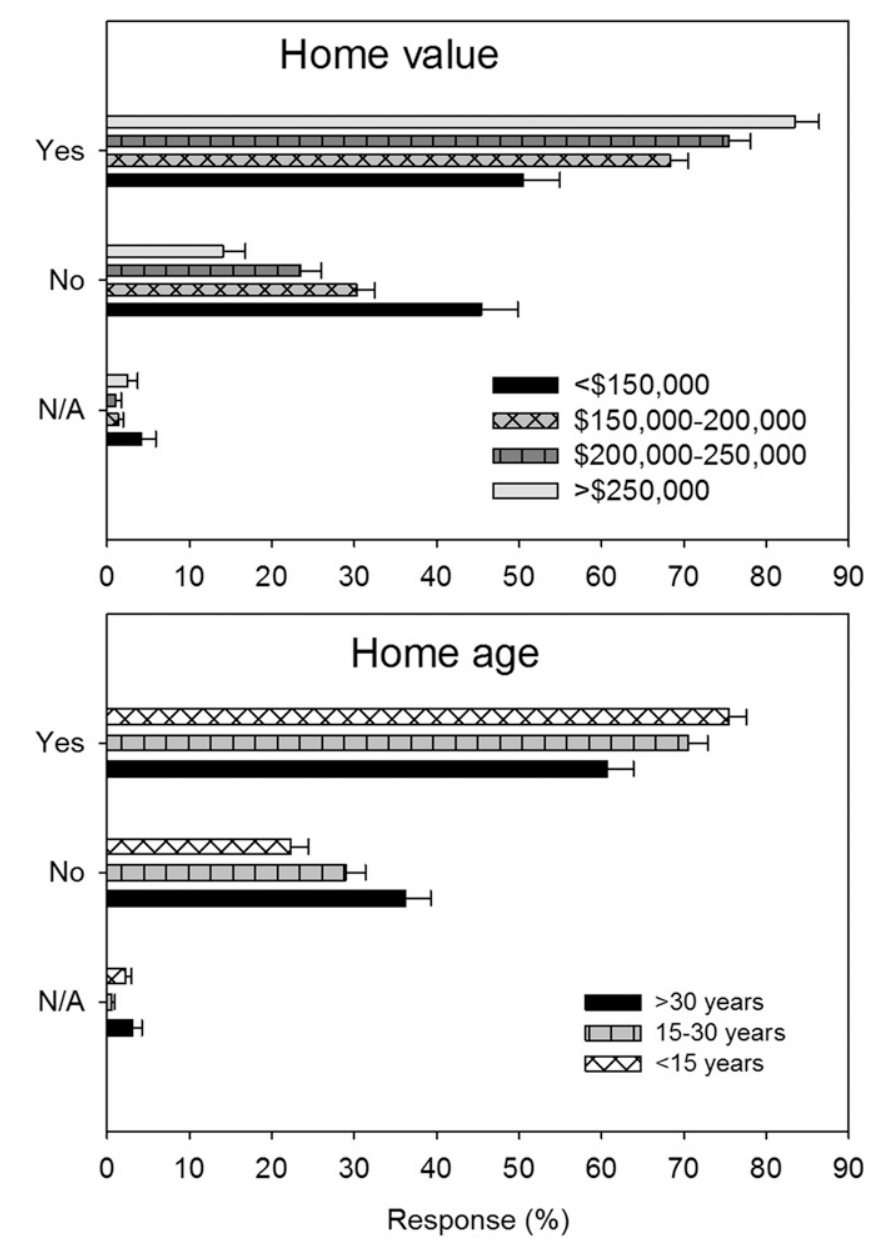

Fig. 6. Responses of residential homeowners in Olathe, KS, grouped by home value and home age, to the question "do you sweep or blow your driveway after mowing (grass clippings)?" Error bars denote SE and N/A indicates not applicable. 
on impervious surfaces, where subsequent precipitation would wash them into storm drains, educational programming concerning lawn care practices that protect surface water quality should definitely include this demographic group.

Responses by Olathe homeowners to the question "do you have an in-ground sprinkler system?" once again showed that the higher the home value, and the newer the home, the more likely homeowners were to have an in-ground system (Fig. 7). Seventy-three percent of highestvalue homeowners had an in-ground system, compared with $41 \%$ of moderately high-value homeowners, and only $14 \%$ and $1 \%$ of moderately lowvalue and lowest-value homeowners, respectively. By home age, 51\% of owners of newer homes had an inground system, compared with 19\% and $5 \%$ of owners of middle-age and oldest-age homes, respectively. Previous research showed that homeowners with in-ground sprinkler systems water more frequently and tend to water on a regular schedule in which irrigation amounts are not adjusted based on lawn requirements (Bremer et al., 2012). Our findings, along with those of Bremer et al. (2012), provide support for focusing educational programming on water conservation toward homeowners of higher-value homes, newer homes, and/or those with in-ground sprinkler systems.

\section{Conclusions}

While owners of homes on large lots were more likely to have an inground sprinkler system and to water on a routine schedule, home value and home age were more important determinants of lawn-watering behaviors. Homeowners of higher-value homes and/or newer homes were more likely to 1) water frequently; 2) water on a regular schedule; 3 ) feel it was very important to have their lawn
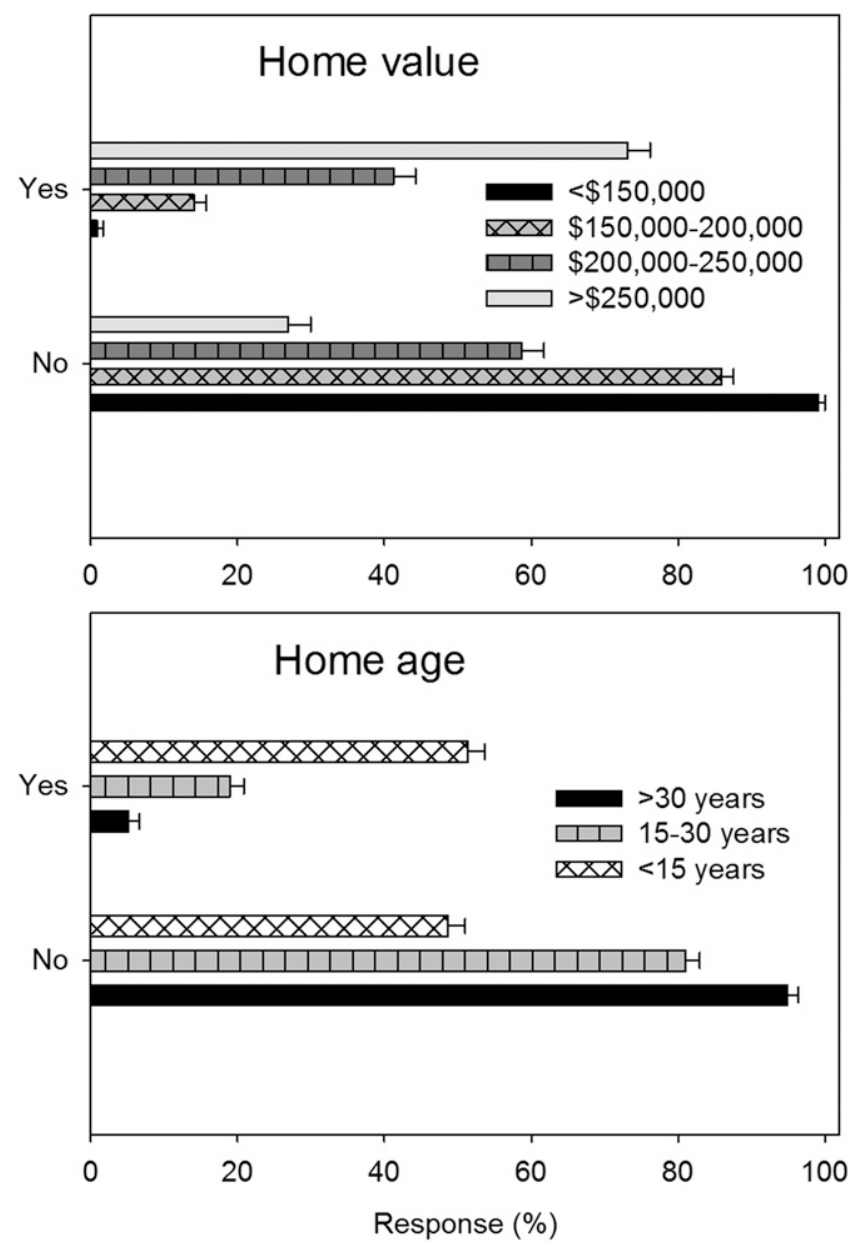

Fig. 7. Responses of residential homeowners in Olathe, KS, grouped by home value and home age, to the question "do you have an in-ground sprinkler system?" Error bars denote $S E$. look green all the time; 4) have an inground sprinkler system; and 5) to sweep or blow grass clippings and lawn care products off impervious surfaces, and to do so back into the lawn rather than into streets or storm drains. Homeowners of lower-value and/or older homes were more likely to 1 ) never water their lawns, or to water infrequently; 2) water based on the lawn's appearance rather than on a regular schedule; 3 ) consider it unimportant to have their lawn appear green all the time, or to be neutral in this regard; 4) not have an in-ground sprinkler system; and 5) leave grass clippings and lawn care products on impervious surfaces rather than blowing them off. Furthermore, the small percentage of lower-value/older-age-home homeowners who did blow clippings or lawn care products off impervious surfaces were more likely than higher-value/ newer-age homeowners to blow them directly into streets or storm drains.

Although this survey was conducted in Kansas, the results probably reflect lawn-watering behaviors elsewhere. Finding effective ways to change lawn-watering perceptions and behaviors, as well as to fill knowledge gaps, should help conserve water and protect water quality in urban watersheds. Based on these survey results and previous research, educational programming on water conservation may be most effective if focused on owners of higher-value homes, newer homes, and those with in-ground sprinkler systems. Educational efforts on preserving surface water quality should be directed at all demographics, but should definitely include owners of lower-value and/or older homes. Specific educational efforts were suggested by Bremer et al. $(2012,2013)$ and may include, but are not limited to applying lawn-irrigation amounts to match the actual needs of the turfgrass (e.g., through the use of SMART controllers on automatic irrigation sprinkler systems, auditing sprinkler systems, educating homeowners about turfgrass water requirements, waiting to irrigate until the lawn shows signs of dryness), encouraging homeowners to follow proper lawn-care guidelines (e.g., sweeping or blowing lawn-care products back into the lawn), encouraging homeowners to allow for some dormancy of turfgrasses during extended drought or hot weather, and 
adapting to turfgrasses with lower water requirements.

\section{Literature cited}

Alig, R.J., J.D. Kline, and M. Lichtenstein. 2004. Urbanization on the US landscape: Looking ahead in the 21 st century. Landsc. Urban Plan. 69:219-234.

Bremer, D.J., S.J. Keeley, A. Jager, and J.D. Fry. 2013. Perceptions and behaviors of residential homeowners in three Kansas [USA] cities: Implications for lawn watering. Intl. Turfgrass Soc. Res. J. 12:23-29.

Bremer, D.J., S.J. Keeley, A. Jager, J.D. Fry, and C. Lavis. 2012. In-ground irrigation systems affect lawn-watering behaviors of residential homeowners. HortTechnology 22:651-658.

Brezonik, P.L. and T.H. Stadelmann. 2002. Analysis and predictive models of stormwater runoff volumes, loads, and pollutant concentrations from watersheds in the Twin Cities metropolitan area, Minnesota. U.S. Water Res. 36:1743-1757.

Carey, R.O., G.J. Hochmuth, C.J. Martinez, T.H. Boyer, M.D. Dukes, G.S. Toor, and J.L. Cisar. 2013. Evaluating nutrient impacts in urban watersheds: Challenges and research opportunities. Environ. Pollut. 173:138-149.

Dietz, M.E. and J. Abraham. 2011. Stormwater monitoring and resident behavior in a semi-arid region. J. Ext. 49:FEA8. <http://www.joe.org/joe/ 2011 april/pdf/JOE_v49_2a8.pdf $>$.

Dey, E.L. 1997. Working with low survey response rates: The efficacy of weighting adjustments. Res. Higher Educ. 38:215227.

Dillman, D.A. 1991. The design and administration of mail surveys. Annu. Rev. Sociol. 17:225-249.

Endter-Wada, J., J. Kurtzman, S.P. Keenan, R.K. Kjelgren, and C.M.U. Neale. 2008. Situational waste in landscape watering: Residential and business water use in an urban Utah Community. J. Amer. Water Resources Assn. 44:902-920.

Grounds Maintenance. 1996. Turf acreage. Grounds Maintenance 31:10.
Hamilton, P.A., T.L. Miller, and D.N Myers. 2004. Water quality in the nation's streams and aquifers-overview of selected findings, 1991-2001. U.S. Geological Survey Cir. 1265. U.S. Geological Survey, Washington, DC.

King, K.W. and J.C. Balogh. 2001. Water quality impacts associated with converting farmland and forests to turfgrass. Trans. Amer. Soc. Agr. Eng. 44:569-576.

Likert, R. 1932. A technique for the measurement of attitudes. Arch. Psychol. 140:1-55

Lohr, S.L. 2010. Sampling: Design and analysis, 2nd ed. Brooks/Cole, Cengage Learning, Boston, MA.

Milesi, C., S.W. Running, C.D. Elvidge, J.B. Dietz, B.T. Tuttle, and R.R. Nemani. 2005. Mapping and modeling the biogeochemical cycling of turf grasses in the United States. Environ. Mgt. 36:426438 .

Morris, K. 2003. The national turfgrass research initiative. Natl. Turfgrass Federation and Natl. Turfgrass Evaluation Program, Beltsville, MD

Morton, T.G., A.J. Gold, and W.M. Sullivan. 1988. Influence of overwatering and fertilization on nitrogen losses from home lawns. J. Environ. Qual. 17:124-130.

Nelson, J. 1992. Water audit encourages residents to reduce consumption. J. Amer. Water Works Assn. 84:59-64.

Petrovic, A.M. 1990. The fate of nitrogenous fertilizers applied to turfgrass. J. Environ. Qual. 19:1-14.

Petrovic, A.M. and Z.M. Easton. 2005. The role of turfgrass management in the water quality of urban environments. Intl. Turfgrass Soc. Res. J. 10:55-69.

Polsky, C., J.M. Grove, C. Knudson, P. Groffman, N. Bettez, J. Cavender Bares, S. Hall, J. Heffernan, S. Hobbie, K. Larson, J. Morse, C. Neill, K. Nelson, L. Ogden, J. O’Neil Dunne, D. Pataki, R. Chowdhury, M. Steele, and R. Roy Chowdhury. 2014. Assessing the homogenization of urban land management with an application to US residential lawn care. Proc. Natl. Acad. Sci. USA 111:44324437.
R Core Development Team. 2011. R: A language and environment for statistical computing. R Foundation for Statistical Computing. 8 Dec. 2014. <http:// www.R-project.org/>

Sewell, S., D. McCallister, R. Gaussoin, and C. Wortmann. 2010. Lawn management practices and perceptions of residents in 14 sandpit lakes of Nebraska. J. Ext. 48:RIB4. <http://www.joe.org/ joe/2010april/rb4.php>.

Scheaffer, R.L., W. Mendenhall, and L. Ott. 1979. Elementary survey sampling, 2nd ed. Duxbury Press, North Scituate, MA.

Sophocleous, M. 1998. Water resources of Kansas: A comprehensive guide, p. 359. In: M. Sophocleous (ed.). Perspectives on sustainable development of water resources in Kansas. Kansas Geological Survey, Lawrence, KS.

U.S. Census Bureau. 2013. American FactFinder: Your source for population, housing, economic, and geographic information. 8 Dec. 2014 . <http:// factfinder2.census.gov>

U.S. Department of Agriculture. 2004. New York turfgrass survey. 8 Dec. 2014. <http://www.nysta.org/news/nystapr/ 2004/Turf book04.pdf>.

U.S. Department of Agriculture. 2006. Maryland turfgrass survey. 8 Dec. 2014. <http://www.nass.usda.gov/Statistics_ by_State/Maryland/Publications / Miscellaneous/turfgrass2006.pdf>.

U.S. Geological Survey. 1999. Analyzing land use change in urban environments. USGS Fact Sheet 188-99. 8 Dec. 2014. <http://landcover.usgs.gov/urban/ info/factsht.pdf>.

U.S. Geological Survey. 2001. Selected findings and current perspectives on urban and agricultural water quality by the National Water-Quality Assessment Program. USGS Fact Sheet 047-01. 8 Dec. 2014. <http://pubs.usgs.gov/fs/ fs- $047-01 />$.

Vickers, A.M. 2001. Handbook of water use and conservation. WaterPlow Press, Amherst, MA. 